\title{
Penerapan Model Learning Cycle 7E Berbantuan Media Visual Untuk Meningkatkan Hasil Belajar Siswa Pada Materi Cahaya KELAS VIII
}

\author{
Siwi Handayani ${ }^{1)}$, Intan Kusumawati ${ }^{2)}$, Haris Rosdianto ${ }^{3)}$ \\ 1) Prodi Pendidikan Fisika STKIP Singkawang \\ E-mail: handayanisiwi06@gmail.com \\ 2) Prodi Pendidikan Fisika STKIP Singkawang \\ E-mail: intankusumawati10@gmail.com \\ 3) Prodi Pendidikan Fisika STKIP Singkawang \\ E-mail: harisrosdianto@yahoo.com
}

\begin{abstract}
Abstrak. Penelitian ini bertujuan untuk mengetahui peningkatan hasil belajar setelah diterapkannya model learning cycle 7E berbantuan media visual pada materi cahaya. Hasil belajar yang diteliti adalah pada ranah kognitif. Bentuk penelitian berupa pre experimental design dengan rancangan One Group Pretest-Posttest Design. Populasi dalam penelitian ini adalah seluruh siswa kelas VIII MTs makarim Al-akhlak dan teknik sampling yang digunakan adalah sampling jenuh. Tes berbentuk pilihan ganda sebanyak 15 soal. Pengkategorian jawaban siswa diadaptasi dari kategori N-gain. Hasil penelitian menunjukkan bahwa peningkatan hasil belajar siswa melalui penerapan model learning cycle 7E berbantuan media visual pada materi cahaya di kelas VIII mengalami peningkatan $N$-gain sebesar 0,42 dengan kriteria sedang.
\end{abstract}

Kata Kunci: Learning Cycle 7E; Hasil Belajar; Media Visual

\section{PENDAhUluan}

Pengetahuan Alam (IPA) merupakan ilmu yang mempelajari tentang fenomena alam dan tentang bagaimana fenomena alam tersebut terjadi secara sistematis [1]. IPA bukan hanya merupakan kumpulan-kumpulan pengetahuan berupa fakta, konsep dan prinsip saja, tetapi juga merupakan suatu proses penemuan [1]. Fakta dan gejala alam tersebut menjadikan pembelajaran IPA tidak hanya verbal tetapi juga faktual [1]. Hal ini menunjukkan bahwa hakikat IPA sebagai proses diperlukan untuk menciptakan pembelajaran IPA yang empirik dan faktual [2] [3].

Tujuan pembelajaran IPA adalah menanamkan rasa ingin tahu dan sikap positif terhadap sains, teknologi dan masyarakat mengembangkan keterampilan proses dan menyelidiki alam sekitar, memecahkan masalah dan membuat keputusan, mengembangkan gejala alam, sehingga siswa dapat berpikir kritis dan objektif [2] [3] [4] [5] [6]. Dalam proses pembelajaran fisika penggunaan media visual juga diperlukan dengan adanya stimulus yang menarik dari media visual tersebut maka peserta didik akan mudah memproses informasi yang diterimanya [7].

Dalam penelitian ini model pembelajaran yang digunakan adalah model learning cylce 7E. Model learning Cycle 7E terdiri dari 7 tahapan, yaitu elicit, engage, explore, explain, elaborate, evaluate dan extend [8-9]. Hasil belajar ranah kognitif berkenaan dengan hasil belajar intelektual yang terdiri dari enam aspek [7] [10] [11], yaitu mengingat (remember), memahami/mengerti (understand), menerapkan (apply), menganalisis (analyze), mengevaluasi (evaluate), menciptakan (create), berbeda dari sebelumnya. Penelitian ini diharapkan dapat berguna bagi peneliti selanjutnya yang ingin meneliti permasalahan yang sama.

\section{METODE}

Jenis penelitian yang digunakan dalam penelitian ini adalah penelitian kuantitatif. Metode yang digunakan pada jenis penelitian ini adalah pre experimental design. Desain penelitian ini adalah one group pre test post test design. Populasi dalam penelitian ini adalah seluruh siswa kelas VIII MTs Makarim Al-akhlak yang terdiri dari satu kelas. Dalam 


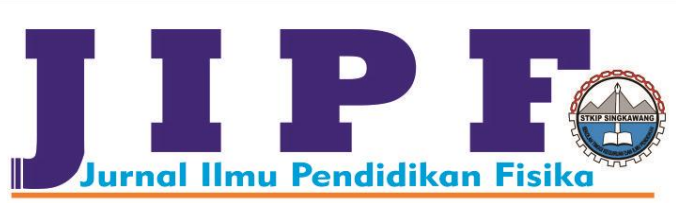

penelitian ini yang menjadi sampel penelitian adalah kelas VIII MTs Makarim Al-akhlak dengan menggunakan teknik nonprobability sampling berupa sampling jenuh. Dikatakan sampling jenuh karena dalam penelitian ini semua anggota populasi digunakan sebagai sampel penelitian [12].

Penelitian ini terdiri dari variabel bebas dan variabel terikat. Variabel bebas dalam penelitian ini adalah model learning cycle 7E, sedangkan variabel terikatnya adalah hasil belajar siswa, aktivitas belajar siswa, dan respon siswa. Teknik pengumpulan data pada penelitian ini menggunakan tes dan observasi. Tes yang diberikan berupa soal pre-test sebelum treatment dan post-test setelah treatment yang diberikan untuk melihat peningkatan hasil belajar siswa.

Adapun instrumen pengumpulan data yang digunakan antara lain (1) lembar observasi aktivitas belajar siswa, (2) lembar respon siswa, (3) lembar pre-test dan post-test. Sebelum tes digunakan dalam penelitian, terlebih dahulu dilakukan uji coba. Data hasil uji coba instrumen kemudian diolah atau dianalisis.

\section{HASIL DAN PEMBAHASAN}

Untuk menggambarkan peningkatan hasil belajar siswa pada materi cahaya, kategori peningkatan hasil belajar diadaptasi dari kategori N-gain [13] sebagai berikut.

TABEL 1

KRITERIA FAKTOR N-GAIN $\langle\mathrm{G}>$

\begin{tabular}{cc}
\hline Skor N-gain & Kategori \\
\hline$<\mathrm{g}>\geq 0,7$ & Tinggi \\
$0,3 \leq<\mathrm{g}><0,7$ & Sedang \\
$<\mathrm{g}><0,3$ & Rendah \\
\hline
\end{tabular}

Peningkatan hasil belajar siswa diperoleh dari hasil ratarata pre test dan rata-rata post test yang dinormalisasii dengan uji gain ternormaisasi. Adapun hasil perhitungan $\mathrm{N}$-gain menggunakan persamaan [13] sebagai berikut.

$$
\begin{aligned}
\langle g\rangle & =\frac{S_{\text {post test }}-S_{\text {pre test }}}{S_{\text {maksimum }}-S_{\text {pre test }}} \\
& =\frac{69,6-47,7}{100-47_{a} 7}=\frac{21_{\imath} 9}{52^{3} 3}=0,42
\end{aligned}
$$

Berdasarkan perhitungan tersebut diungkapkan bahwa skor rata-rata hasil belajar siswa setelah dinormalisasikan dengan uji $\mathrm{N}$-gain diperoleh peningkatan nilai sebesar 0,42 , maka hasil belajar siswa diperoleh peningkatan dengan kriteria sedang karena 0,42 berada pada rentang $0,3 \leq\langle\mathrm{g}\rangle\langle 0,7$. Peningkatan hasil belajar ranah kognitif siswa merupakan perubahan yang ditimbulkan sebelum dan sesudah proses pembelajaran berlangsung. Apabila dikaji dari standar Kriteria Ketuntasan Minimal (KKM) pelajaran fisika sebesar 65,00 maka nilai rata-rata post test hasil belajar siswa sudah mencapai standar KKM. Nilai rata-rata hasil belajar siswa pada post test sebesar 69,6 . Hal ini membuktikan bahwa model pembelajaran learning cycle $7 \mathrm{E}$ berbantuan media
Jurnal Ilmu Pendidikan Fisika

Volume 3 Number 2 month September 2018. Page 35-37 p-ISSN: 2477-5959 e-ISSN: 2477-8451

visual dapat meningkatkan hasil belajar siswa ada materi cahaya di kelas VIII MTs Makarim Al-akhlak.

\section{KESIMPULAN}

\section{A. Simpulan}

Berdasarkan hasil dan pembahasan yang dilakukan dapat disimpulkan bahwa terdapat peningkatan hasil belajar siswa sebesar 0,42 dengan kriteria sedang.

\section{B. Saran}

Model learning cycle 7E berbantuan media visual dapat meningkatkan hasil belajar siswa dan sebaiknya digunakan juga pada materi fisika yang berbeda.

\section{DAFTAR PUSTAKA}

[1] Depdiknas. (2006). Kurikulum Tingkat Satuan Pendidikan (KTSP). Jakarta: Departemen Pendidikan Nasional.

[2] Irhamna, Rosdianto, H., \& Murdani, E. (2017). Penerapan Model Learning Cycle 5E untuk Meningkatkan Keterampilan Berpikir Kritis Siswa Pada Materi Fluida Statis Kelas VIII. Jurnal Fisika Flux, 14(1): 61-64.

[3] Nadiya, Rosdianto, H., \& Murdani, E. (2016). Penerapan Model Pembelajaran Group Investigation (GI) untuk Meningkatkan Keterampilan Berpikir Kritis Siswa pada Materi Gerak Lurus Kelas X. JIPF (Jurnal Ilmu Pendidikan Fisika), 1(2): 49-51.

[4] Rosdianto, H., Murdani, E., \& Hendra. (2017). Implementasi Model Pembelajaran POE (Predict Observe Explain) Untuk Meningkatkan Pemahaman Konsep Siswa Pada Materi Hukum Newton. Jurnal Pendidikan Fisika, 6(1): 55-57.

[5] Rosdianto, H. (2017). Students Conceptual Understanding through Generative Learning Model in Topic "Light". JPI (Jurnal Pendidikan Indonesia), 6(2): 259-262.

[6] Siradjuddin, Rosdianto, H., \& Sulistri, E. (2018). Penerapan Model REACT Untuk Meningkatkan Keterampilan Proses Sains Siswa Pada Materi Arus Listrik. Jurnal Pendidikan Fisika dan Keilmuan (JPFK), 4(1): 17-22.

[7] Habaib, M. (2009). Efektifitas Penggunaa Media Pembelajaran visual dalam meningkatkan Hasil Belajar Fisika Materi Pokok Gerak Lurus (Studi pada siswa kelas X MA YPPA cipulus wanayasa purwakarta) (Doctoral dissertation ,IAIN Walisongo).

[8] Rosmaiyadi. (2017). Analisis Kemampuan Berpikir Kritis Matematis Siswa dalam Learning Cycle 7E Berdasarkan Gaya Belajar. AKSIOMA: Jurnal Program Studi Pendidikan Matematika, 6(1): 12-19

[9] Lisma, Kurniawan, Y., \& Sulistri, E. (2017). Penerapan Model Learning Cycle (LC) 7E Sebagai Upaya Peningkatan Pemahaman Konsep Aspek Menafsirkan dan Menyimpulkan Materi Kalor Kelas X SMA. JIPF (Jurnal Ilmu Pendidikan Fisika), 2(2): 35-37. 
[10] Rosdianto, H. (2017). Pengaruh Model Generative Learning Terhadap Hasil Belajar Ranah Kognitif Siswa Pada Materi Hukum Newton. Jurnal Pendidikan Fisika dan Keilmuan (JPFK), 3(2), 66-69.

[11] Herniati, R., Sulistri, E., \& Rosdianto, H. (2017). Penerapan Model Predict Observe Explain Dengan Pendekatan Learning by Doing Untuk Meningkatkan Hasil Belajar Siswa. Jurnal Fisika FLUX, 14(2): 120124.

[12] Sugiyono. (2008). Metode Penelitian Pendidikan. Bandung: Alfabeta.

[13] Hake, R. (1999). Interactive-engagement Methods In Introductory Mechanics Course. (Online). Tersedia: http//www.Physic.Indiana.edu/-sdi/IEM-2b.pdf. Diakses 8 April 2015 